\title{
Pengenalpastian dan Profil Pengekspresan Gen Biosintesis Asid Amino Yis Psikrofil, Glaciozyma antarctica
}

(Identification and Expression Profiles of Amino Acid Biosynthesis Genes

from Psychrophilic Yeast, Glaciozyma antarctica)

\author{
IZWAN BHARUdin, RADZIAH ZOLKEFLI, MOHD FAIZAL ABU BAKAR, SHAZILAH KAMARUdDIN, ROSLI Md. ILLIAS, \\ NAZALAN NAJIMUdin, NOR MUHAMMAD MAHADI, FARAH DiBA ABU BAKAR \\ \& ABDUl MuniR ABDUl MURAD*
}

\begin{abstract}
ABSTRAK
Mekanisme pengambilan dan penghasilan asid amino bagi mikroorganisma psikrofil yang bermandiri dan berpoliferasi pada persekitaran sejuk melampau masih belum difahami sepenuhnya. Objektif kajian ini ialah untuk mengenal pasti gen yang terlibat dalam penjanaan asid amino bagi yis psikrofil, Glaciozyma antarctica serta menentukan pengekspresan gen tersebut semasa kehadiran dan kekurangan asid amino dalam medium pertumbuhan. Pengenalpastian gen telah dilakukan melalui penjanaan penanda jujukan terekspres (ESTs) daripada dua perpustakaan cDNA yang dibina daripada sel yang dikultur dalam medium pertumbuhan kompleks dan medium pertumbuhan minimum tanpa asid amino. Sebanyak 3552 klon cDNA daripada setiap perpustakaan dipilih secara rawak untuk dijujuk menghasilkan 1492 transkrip unik (medium kompleks) dan 1928 transkrip unik (medium minimum). Analisis pemadanan telah mengenl pasti gen mengekod protein yang terlibat di dalam pengambilan asid amino bebas, biosintesis asid amino serta gen yang terlibat dengan kitar semula asid amino berdasarkan tapak jalan yang digunakan oleh yis model, Saccharomyces cerevisiae. Analisis pengekspresan gen menggunakan kaedah RT-qPCR menunjukkan pengekspresan gen mengekod protein yang terlibat di dalam pengambilan asid amino bebas iaitu permease adalah tinggi pada medium kompleks manakala pengekspresan kebanyakan gen mengekod protein yang terlibat dalam kitar semula dan biosintesis asid amino adalah tinggi di dalam medium minimum. Kesimpulannya, gen yang terlibat dalam penjanaan dan pengambilan asid amino bagi mikroorganisma psikrofil adalah terpulihara seperti mikroorganisma mesofil dan pengekspresan gen-gen ini adalah diaruh oleh kehadiran atau ketiadaan asid amino bebas pada persekitaran.
\end{abstract}

Kata kunci: Biosintesis asid amino; Glaciozyma antarctica; penanda jujukan terungkap; psikrofil

\section{ABSTRACT}

The mechanism of amino acid uptake and synthesis in the psychrophilic microorganism lives and proliferate in the extreme low-temperature environment is still not well understood. The aim of this study was to identify genes involved in amino acid generation for psychrophilic yeast, Glaciozyma antarctica and to determine their expression profiles when cells grow in media rich in amino acids or with limited amount of amino acids. The identification of genes was carried out by generating expressed sequence tags (EST) from two CDNA libraries generated from cells grown in complex growth medium and minimal growth medium without amino acids. A total of 3552 cDNA clones from each library was randomly picked and sequenced, generating 1492 unique transcripts (complex medium) and 1928 unique transcripts (minimal medium). Homology analyses have identified genes encoding proteins required for free amino acid uptake, biosynthesis of amino acids and recycling of amino acids based on the pathway used in the model yeast, Saccharomyces cerevisiae. Gene expression analysis by RT-qPCR showed that genes required for free amino acid uptake showed a higher expression profile in the complex medium, whereas the expression of most genes encode for proteins essential for biosynthesis and recycling of amino acids are higher in the minimal medium. In summary, genes that are involved in the generation and the uptake of amino acids for psychrophilic microorganism are conserved as in their mesophilic counterparts and the expression of these genes are regulated in the presence or absent of free amino acids in the surrounding.

Keywords: Amino acid biosynthesis; expressed sequence tag; Glaciozyma antarctica; psychrophiles

\section{PENDAhuluan}

Persekitaran yang sejuk merupakan persekitaran yang paling banyak meliputi permukaan bumi dan pelbagai organisma psikrofil seperti bakteria dan kulat dapat mendiami dan berpoliferasi di persekitaran tersebut. Organisma psikrofil ditakrifkan sebagai organisma yang mampu bermandiri pada suhu yang sejuk di bawah $15^{\circ} \mathrm{C}$ (Moyer \& Morita 2007). Untuk bertahan pada suhu yang 
rendah, mikroorganisma psikrofil telah berevolusi bagi menjamin kemandiriannya. Cabaran utama organisma psikrofil untuk berkembang dan membiak pada habitatnya adalah kelikatan persekitaran berair, kekurangan nutrien dan suhu rendah ekstrem yang menggangu aktiviti dalaman sel seperti aktiviti enzim, kebendaliran membran, pengekspresan gen serta sintesis protein (D’Amico et al. 2006).

Pada persekitaran semula jadi, mikroorganisma terdedah kepada kehadiran nutrien yang pelbagai bergantung kepada keadaan habitatnya. Kekurangan sesuatu nutrien akan mengehadkan pertumbuhan sel dan ini membuka peluang untuk kajian penyelarasan penderiaan nutrien, metabolisme, pertumbuhan sel dan pembahagian sel (Petti et al. 2011). Jangka hayat sel mikroorganisma semasa kekurangan nutrien bergantung sepenuhnya kepada jenis nutrien yang hilang. Secara umumnya, kekurangan nutrien semula jadi seperti sumber karbon, fosfat dan nitrogen akan menyebabkan kematian sel (Boer et al. 2008), tetapi kekurangan nutrien seperti asid amino akan mengakibatkan mikroorganisma kehilangan keupayaan untuk hidup dan berpoliferasi (Spellman et al. 1998). Secara umumnya, mikroorganisma memperoleh asid amino dengan tiga cara utama iaitu membawa masuk asid amino bebas yang hadir di persekitaran sel, mensintesis asid amino dengan bantuan enzim yang hadir di dalam sel serta mengitar semula asid amino daripada protein dalaman sel yang telah rosak (Finley et al. 2012; Payne \& Loomis 2006; Springael \& André 1998).

Glaciozyma antarctica merupakan yis psikrofil obligat yang dipencil daripada ais laut di Antartika dan mempunyai suhu pertumbuhan optimum pada $4^{\circ} \mathrm{C}$ dan tidak mampu hidup pada suhu melebihi $20^{\circ} \mathrm{C}$ (Hashim et al. 2013). Ciri-ciri ini membolehkan $G$. antarctica digunakan sebagai model bagi memahami bagaimana mikroorganisma psikrofil beradaptasi pada persekitaran sejuk lampau (Firdaus-Raih et al. 2018). Dalam kajian ini, pengenalpastian gen yang terlibat dalam pengambilan dan penjanaan asid amino oleh G. antarctica telah dilakukan. Kaedah penjujukan EST daripada dua perpustakaan cDNA yang dibina daripada sel yang dikultur dalam medium pertumbuhan kompleks dan medium pertumbuhan minimum tanpa asid amino telah dilakukan bagi memperoleh gen yang berkaitan. Selain itu, bagi menentukan sama ada mekanisme penjanaan asid amino bagi mikroorganisma psikrofil adalah terpulihara seperti di dalam mikroorganisma mesofil, kajian berkaitan tahap pengekspresan gen yang terlibat dalam tapak jalan biosintesis dan kitar semula asid amino dilakukan terhadap sel yang dihidupkan di dalam dua medium pertumbuhan berbeza; iaitu medium kompleks dan medium minimum. Berdasarkan kajian kepustakaan yang dilakukan, ini merupakan kajian pertama seumpamanya untuk mengenal pasti gen-gen yang terlibat penjanaan asid amino bagi mikroorganisma psikrofil.

\section{BAHAN DAN KAEDAH}

\section{PENGKULTURAN GLACIOZYMA ANTARCTICA PI12}

Glaciozyma antarctica yang digunakan dalam kajian ini diperoleh daripada Unit Penyimpanan Kultur Mikroorganisma, Pusat Pengajian Biosains dan Bioteknologi, Universiti Kebangsaan Malaysia (Hashim et al. 2013). Untuk menghidupkan sel, koloni tunggal $G$. antarctica diinokulatkan ke dalam $10 \mathrm{~mL}$ medium kompleks (YPD) yang mengandungi antibiotik kanamisin $(50 \mu \mathrm{g} / \mathrm{mL})$ dan ampisilin $(50 \mu \mathrm{g} / \mathrm{mL})$ dan sel dihidupkan selama 5 hari pada $4^{\circ} \mathrm{C}$. Untuk pembinaan perpustakaan cDNA teraruh, sebanyak $1.0 \times 10^{7}$ sel dipindahkan ke dalam $100 \mathrm{~mL}$ medium kompleks (YPD) dan $100 \mathrm{~mL}$ medium minimum (YNB tanpa asid amino). Sel dieram pada $4^{\circ} \mathrm{C}$ selama 5 hari dengan goncangan 180 ppm. Selepas 5 hari, sel dituai dengan emparan pada kelajuan 10000 ppm selama 5 min dan disimpan pada $-80^{\circ} \mathrm{C}$ sehingga digunakan.

\section{PEMBINAAN PERPUSTAKAAN CDNA DAN ANALISIS KUALITI EST}

Pengekstrakan RNA jumlah dilakukan mengikut kaedah seperti yang diterangkan oleh Bharudin et al. (2014). Pemencilan mRNA pula dilakukan dengan menggunakan kit mRNA PolyAttract ${ }^{\circledR}$ mRNA Isolation System (Promega, USA). Kualiti RNA jumlah dan mRNA yang diekstrak ditentu menggunakan kit Bioanalyzer RNA Nanochip (Agilent Technologies, USA). Pembinaan perpustakaan cDNA dilakukan menggunakan kit CloneMiner ${ }^{\mathrm{TM}}$ cDNA Library Construction Kit (Invitrogen, USA) mengikut kaedah yang dicadangkan oleh pengeluar. Seterusnya, klon cDNA dijujuk menggunakan mesin penjujukan berautomasi ABI PRISM® 3730×1 DNA Analyzer (Applied Biosystem, USA) menggunakan pencetus kehadapan M13 (5'-GTA AAA CGA CGG CCA G-3'). Jujukan DNA disunting menggunakan program Phred (Ewing \& Green 1998) manakala jujukan EST dikelompok menggunakan program StackPACK ${ }^{\mathrm{TM}}$ v2.2 (George 2001). Dalam kajian ini, penamaan gen dan protein $G$. antarctica adalah berpandukan sistem penamaan bagi yis Saccharomyces serevisiae (http://genome-www.stanford. edu/ Saccharomyces/).

\section{ANALISIS HOMOLOGI PROTEIN GLACIOZYMA ANTARCTICA BAGI METABOLISME ASID AMINO}

Jujukan EST yang terhasil dibandingkan dengan jujukan lain di dalam pangkalan data Genbank menggunakan perisian BLAST2GO (Conesa et al. 2005). Seterusnya, analisis Ontologi Gen (GO) dilakukan untuk mengklasifikasikan protein bergantung kepada fungsi berdasarkan piawaian konsortium GO yang ditetapkan. Bagi mengenal pasti jujukan protein yang terlibat di dalam metabolisme asid amino, analisis perbandingan dilakukan dengan menggunakan pangkalan data projek genom S. cerevisiae (http://www.yeastgenome.org/ cgi-bin/seqTools). Pasangan homolog yang hadir di 
dalam pangkalan data EST $G$. antarctica bagi jujukan tersebut dianalisis menggunakan program BLASTP dengan kesignifikanan ditetapkan kepada nilai E kurang daripada $10^{-5}$. Kemudian, beberapa gen mengekod protein yang terlibat dalam kedua-dua proses dipilih sebagai calon untuk kajian pengekspresan gen menggunakan kaedah RT-qPCR berdasarkan penemuan jujukan EST daripada perpustakaan cDNA G. antarctica yang dibina.

\section{ANALISIS PENGEKSPRESAN GEN MENGGUNAKAN KAEDAH TRANSKRIPSI-BERBALIK KUANTITATIF TINDAK BALAS BERANTAI POLIMERASE (RT-qPCR)}

Penulenan RNA jumlah dilakukan menggunakan Kit RNeasy Mini (Qiagen, Jerman). Tindak balas RT-qPCR dijalankan dalam campuran $20 \mu \mathrm{L}$ yang mengandungi 10 $\mu \mathrm{L}$ campuran $2 \times$ QuantiFast SYBR Green RT-PCR (Qiagen, Jerman $), 0.8 \mu \mathrm{L}(25 \mathrm{pmol})$ pencetus kehadapan dan kebelakang (Jadual 1), 7.2 $\mu \mathrm{L}$ air bebas nukleus, $100 \mathrm{ng}$ RNA jumlah dan $0.2 \mu \mathrm{L}$ QuantiFast Reverse Transcriptase (Qiagen, Jerman). Tindak balas RT-qPCR yang dijalankan melibatkan sintesis bebenang cDNA pada suhu $50^{\circ} \mathrm{C}$ selama 10 min diikuti dengan pengaktifan enzim HotStar Taq Plus DNA polimerase pada suhu $95^{\circ} \mathrm{C}$ selama $5 \mathrm{~min}$. Tindak balas diteruskan dengan 40 kitaran pada suhu $95^{\circ} \mathrm{C}$ selama $10 \mathrm{~s}$ dan pengesanan serta pengambilan data pada suhu $60^{\circ} \mathrm{C}$ selama $30 \mathrm{~s}$ diikuti dengan analisis lengkuk peleburan. Setiap sampel diulang dalam tiga replikasi teknikal dan tiga replikasi biologi serta satu set kawalan negatif menggunakan mesin Mastercycler ${ }^{\circledR}$ ep Realplex (Eppendorf, Jerman). Perisian GenEX (versi 4.4.2.308, MultiD, Sweden) digunakan dalam analisis pengiraan tahap pengekspresan gen-gen yang dikaji dalam kajian ini. Gen $18 \mathrm{~S}$ rRNA dan beta-aktin digunakan sebagai gen kawalan untuk membetulkan variasi antara sampel. Analisis statistik analisis varians satu-hala (one-way ANOVA) dilakukan menggunakan perisian Minitab 15 (Minitab Inc., USA).

\section{KEPUTUSAN DAN PERBINCANGAN}

\section{PEMBINAAN PERPUSTAKAAN DAN ANALISIS JUJUKAN} CDNA GLACIOZYMA ANTARCTICA

Dua perpustakaan cDNA daripada mRNA yang diperoleh daripada yis yang dikulturkan dalam dua medium berbeza iaitu medium kompleks dan medium minimum telah dibina. Jumlah titer perpustakaan cDNA bagi medium pertumbuhan kompleks dan medium pertumbuhan minimum masing-masing adalah $6 \times 10^{4}$ dan $9.4 \times 10^{6}$ cfu. Jumlah titer ini adalah setara dengan jumlah titer yang diperoleh bagi pembinaan perpustakaan cDNA kulat Trichoderma virens (Murad et al. 2013) dan Aspergillus niger (Tang et al. 2012). Ciri-ciri perpustakaan cDNA dan hasil analisis penjujukan EST $G$. antarctica bagi kedua-dua medium diberikan dalam Jadual 2. Hasil menunjukkan perpustakaan cDNA yang dijana adalah baik kerana mempunyai bilangan klon positif yang tinggi, saiz fragmen cDNA yang panjang dan mengandungi populasi gen berbeza dengan tinggi. Julat saiz selitan cDNA bagi medium kompleks adalah antara 300 dan 1700 pb manakala bagi perpustakaan cDNA medium minimum pula adalah antara 400 dan 2000 pb berdasarkan analisis pemotongan dengan enzim penyekatan $B s r G 1$. Purata saiz selitan cDNA bagi kedua-dua perpustakaan cDNA adalah 940 pb (Jadual 2). Saiz cDNA yang diperoleh ini menunjukkan bahawa kebanyakan cDNA yang dihasilkan adalah panjang (melebihi $500 \mathrm{pb}$ ) dan berkemungkinan besar mengandungi sekurang-kurangnya sebahagian rangka bacaan terbuka bagi sesuatu gen. Oleh yang demikian, klon cDNA ini amat berguna dalam analisis pengenalpastian gen kerana cDNA berasal daripada mRNA yang merupakan jujukan pengekodan. Maka, kebarangkalian untuk mendapatkan hasil yang signifikan dalam analisis pemadanan jujukan bagi klon-klon cDNA tersebut adalah tinggi (Sterky \& Lundeberg 2000).

JADUAL 1. Senarai pencetus yang digunakan dalam analisis RT-qPCR

\begin{tabular}{lll}
\hline Gen & Pencetus & Jujukan pencetus spesifik (5'-3') \\
\hline 18S RNA & 18 S-F & ACCAGGTCCAGACACAAT \\
& 18 S-R & TAACCAGACAAATCACTC \\
Beta-aktin & aktin-F & CATCTACGAGGGTTACGC \\
& aktin-R & GCATCTCCTGCTCAAAGTC \\
Enzim pengaktif ubikuitin & E1-F & GACGAGTTTGGCGAC \\
& E1-R & CGATGAAGAAGCGGT \\
Enzim konjugasi ubikuitin & E2-F & CCAACAGCATCGTCAGC \\
& E2-R & GGTAGTCGGTCGGGAAA \\
Enzim ubikuitin ligase & E3-F & TCTACATCCTCGCCCT \\
& E3-R & CTCGTCCAATCCCAAC \\
Permease umum & Gap1-F & TCGCTGAGGAAGAG \\
& Gap1-R & GCGGTAACGAAGAC \\
Permease prolina & Put4-F & TCGGTGGTGCTATCG \\
& Put4-R & CGGAGAATCCCTTGC \\
\hline
\end{tabular}


Analisis pengkelompokan yang dilakukan menunjukkan sebanyak 659 EST (medium kompleks) dan 558 EST (medium minimum) membentuk jujukan konsensus (beberapa jujukan EST yang sama membentuk konsensus). Sebanyak 833 EST (medium kompleks) dan 1370 EST (medium minimum) pula membentuk jujukan tunggal (Jadual 2). Analisis peratus kekerapan menjujuk jujukan yang sama memberikan hasil yang berbeza dengan $52.4 \%$ (medium kompleks) dan $42.5 \%$ (medium minimum) (Jadual 2). Analisis ini penting kerana semakin tinggi peratus kekerapan yang diperoleh, kebarangkalian untuk memperoleh jujukan EST yang baru akan berkurangan (Susko \& Roger 2004) yang seterusnya boleh menyebabkan kerugian masa, tenaga dan wang. Semua jujukan EST yang terhasil telah didaftarkan di dalam pangkalan data GenBank.

\section{ANOTASI DAN ONTOLOGI GEN}

Analisis perbandingan yang dijalankan menggunakan program BLAST2GO (Conesa et al. 2005) mendapati sekitar $70 \%$ sahaja jujukan EST daripada kedua-dua perpustakaan cDNA mempunyai persamaan homologi (E-value $<10^{-5}$ ) dengan jujukan di dalam pangkalan data non-redundant $(n r)$ di National Center for Biotechnology Information (NCBI). Seterusnya, analisis kefungsian protein dijalankan untuk mengklasifikasi setiap transkrip unik mengikut piawaian konsortium GO yang ditetapkan. Ontologi gen terbahagi kepada tiga kumpulan utama iaitu fungsi molekul, proses biologi dan komponen sel.

Kumpulan aktiviti katalitik merupakan kumpulan yang berada di bawah pengelasan kefungsian kumpulan fungsi molekul. Analisis mendapati bilangan transkrip unik perpustakaan cDNA medium minimum lebih tinggi berbanding medium kompleks (Rajah 1(A)). Protein yang dikelompok di bawah kumpulan aktiviti katalitik merupakan enzim atau bahan pemangkin yang terlibat dengan perubahan kadar tindak balas kimia yang berlaku di dalam sel seperti kumpulan transferase dan kumpulan oksireduktase. Bagi kumpulan proses biologi pula, kumpulan metabolik dan kumpulan sel merupakan dua kumpulan yang menunjukkan peratusan transkrip unik tertinggi yang ketara berbanding kumpulan proses biologi yang lain (Rajah 1(B)). Dalam kedua-dua kumpulan tersebut, bilangan transkrip unik bagi medium minimum adalah lebih tinggi berbanding medium kompleks. Antara kumpulan proses yang dikelaskan dalam GO kumpulan biologi adalah seperti proses pengekspresan gen, pengubahsuaian protein dan interaksi protein-substrat yang penting dalam mengawal frekuensi proses biologi di dalam sel. Analisis Go bagi kumpulan komponen sel pula mengelompokkan kata nama protein yang terlibat dalam pembinaan keperluan asas sel atau organisma. Didapati lebih daripada $30 \%$ jujukan EST daripada kedua-dua perpustakaan cDNA dikelompokkan di bawah komponen sel, diikuti dengan komponen organel dan kumpulan kompleks makromolekul. Kedua-dua komponen ini mencatatkan peratusan tertinggi bagi perpustakaan cDNA medium kompleks berbanding perpustakaan cDNA medium minimum (Rajah 1(C)). Protein yang dikelompokkan di bawah ketiga-tiga komponen ini terlibat di dalam pembinaan keperluan asas sel seperti membran sel, nukleus, ribosom, asid nukleik dan karbohidrat.

\section{ANALISIS KUMPULAN PENGAMBILAN ASID AMINO BEBAS}

Terdapat dua tapak jalan pengesan nutrien di dalam yis yang telah dikaji dengan baik iaitu tapak jalan pengesan glukosa (Schmidt et al. 1999) dan tapak jalan pengesan asid amino (Klasson et al. 1999). Bagi mikroorganisma

JADUAL 2. Ringkasan ciri perpustakaan cDNA dan hasil analisis penjujukan EST Glaciozyma antarctica bagi medium kompleks dan medium minimum

\begin{tabular}{|c|c|c|}
\hline Perpustakaan cDNA & Medium kompleks & Medium minimum \\
\hline Titer primer ${ }^{\mathrm{a}}(\mathrm{cfu} / \mathrm{mL})$ & $1.0 \times 10^{4}$ & $2.3 \times 10^{6}$ \\
\hline Jumlah CFU & $6.0 \times 10^{4}$ & $9.40 \times 10^{6}$ \\
\hline Peratus rekombinan $(\%)$ & 93.0 & 96.4 \\
\hline Julat saiz selitan cDNA (pb) & $300-1700$ & $400-2000$ \\
\hline Bil. klon dijujuk & 3552 & 3552 \\
\hline Bil. jujukan berkualiti tinggi (\%) & $3134(88.2 \%)$ & $3351(94.3 \%)$ \\
\hline Purata panjang jujukan (pb) & 599 & 538 \\
\hline Bilangan konsensus ${ }^{\mathrm{b}}$ & 659 & 558 \\
\hline Bilangan EST tunggal $^{\mathrm{c}}$ & 833 & 1370 \\
\hline Bilangan transkrip unik ${ }^{\mathrm{d}}$ & 1492 & 1928 \\
\hline Peratus kekerapan ${ }^{\mathrm{e}}$ & 52.4 & 42.5 \\
\hline $\begin{array}{l}\text { Titer primer bagi perpustakaan cDNA dipe } \\
\text { Titer primer }(\mathrm{cfu} / \mathrm{mL})=\text { Bilangan koloni ya } \\
\text { Isi padu sampel yang dipiringkan }(\mathrm{mL}) \\
\text { Jujukan konsensus yang diperoleh melalui } \\
\text { J Jujukan EST yang tidak dikelompok melal } \\
\text { d Hasil jumlah konsensus dan EST tunggal } \\
\text { Peratus kekerapan yang diperoleh berdasar } \\
\text { Bilangan EST berkualiti tinggi - Bilangan }\end{array}$ & $\begin{array}{l}\text { sarkan formula berikut: } \\
\text { di atas piring } \times \text { Faktor pen } \\
\text { AW } \\
\text { pengkelompokan } d 2 \_ \text {cluster } \\
\text { a berikut: } \\
\text { hik } \times 100 \%\end{array}$ & \\
\hline
\end{tabular}



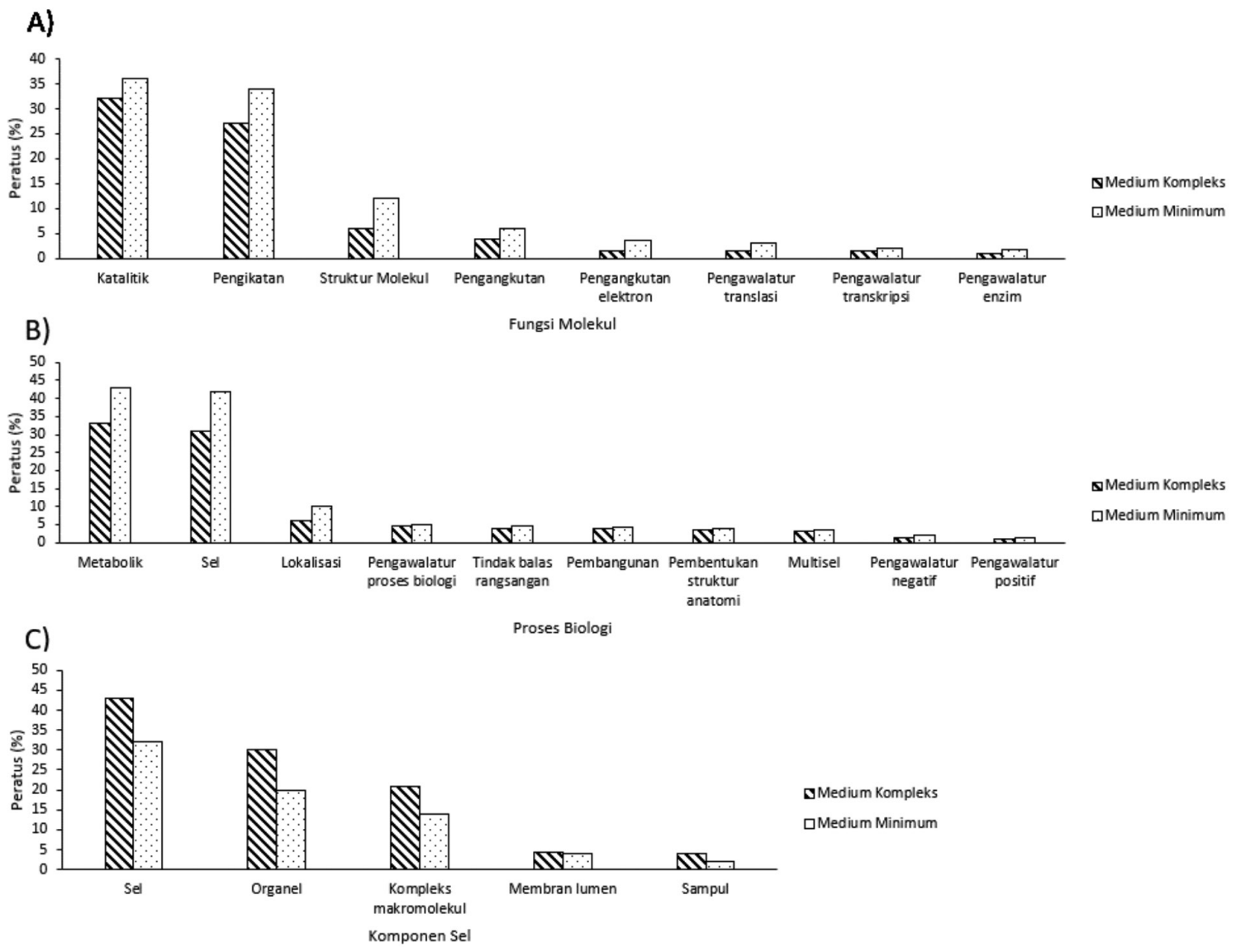

RAJAH 1. Analisis pengkelasan kefungsian protein berdasarkan piawaian ontologi gen (GO) bagi kedua-dua perpustakaan cDNA G. antarctica (A) fungsi molekul, (B) proses biologi dan (C) komponen sel

yis model, S. cerevisiae, kehadiran asid amino di luar sel dikesan melalui dua kumpulan keluarga pengangkut asid amino iaitu Gap1/Ssy1 melalui sistem pengesan-sensor SPS yang berhomolog dengan asid amino permease (Iraqui et al. 1999). Analisis jujukan EST G. antarctica tidak menemui klon yang berhomolog dengan sistem SPS. Namun begitu, terdapat dua pengangkut asid amino telah dikenal pasti hadir di dalam pangkalan data EST $G$. antarctica iaitu permease umum (GAPl) dan permease prolina (PUT4). Kedua-dua protein ini (Gap1 dan Put4) merupakan pengangkut asid amino yang telah dicirikan dengan baik di dalam $S$. cerevisiae dan berfungsi sebagai pengesan kehadiran asid amino (Thevelein et al. 2005). Permease umum (Gap1) mempunyai kapasiti pengangkut-protein yang lebih tinggi berbanding permease prolina (Put4) kerana Gap1 berkebolehan untuk mengangkut semua asid amino secara semula jadi (L-asid amino dan D-asid amino) (Jørgensen et al. 1998) manakala Put4 hanya berkebolehan untuk mengangkut asid amino spesifik prolina sahaja (Andréasson et al. 2004).

Hasil analisis homologi menunjukkan hanya terdapat satu jujukan EST GAP1 yang berhomolog dengan protein $S$. cerevisiae dan ia hadir di dalam perpustakaan cDNA medium minimum manakala dua jujukan EST PUT4 ditemui, satu daripada setiap perpustakaan cDNA. Namun, bilangan jujukan EST yang hadir di dalam setiap perpustakaan cDNA ini tidak menggambarkan kadar pengekspresan sebenar berikutan pemilihan klon yang dijalankan di dalam kajian ini adalah secara rawak dan terhad (Stekel et al. 2000). Oleh yang demikian, dua jujukan EST $G$. antarctica dengan setiap satunya mewakili GAPl dan PUT4 telah dipilih untuk analisis pengekspresan gen masing-masing di dalam medium pertumbuhan kompleks dan minimum.

Analisis pengekspresan gen kedua-dua protein permease tersebut mendapati kadar pengekspresan kedua-dua gen (GAPl dan PUT4) adalah lebih tinggi di dalam medium kompleks berbanding medium minimum (Rajah 2). Penggunaan sebatian ammonium sulfat sebagai sumber nitrogen di dalam medium minimum yang digunakan di dalam kajian ini mungkin telah menghalang aktiviti transkripsi dan seterusnya mengurangkan kadar pengekspresan gen-gen permease tersebut. Kajian terdahulu membuktikan bahawa kehadiran ammonia $\left(\mathrm{NH}_{4}\right)$, glutamina atau asparagina sebagai sumber nitrogen di dalam medium pertumbuhan akan menghalang proses trankripsi dan pembangunan aktiviti protein permease (Springael \& André 1998). Manakala sumber nitrogen di dalam medium pertumbuhan kompleks adalah tidak terhad kepada mana-mana sebatian ammonia dan menyebabkan gen mengekod kedua-dua protein permease tersebut diekspres dengan tinggi (Zhang et al. 2016). 


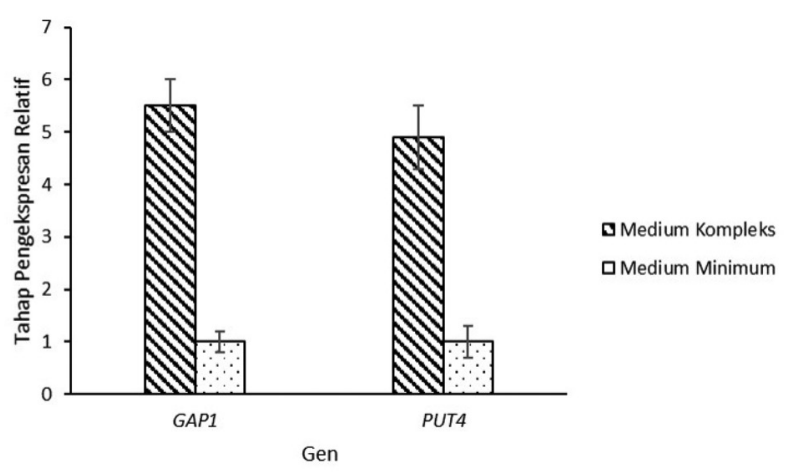

RAJAH 2. Analisis tahap pengekspresan relatif bagi gen mengekod protein permease umum $(G A P 1)$ dan permease prolina (PUT4) daripada kumpulan pengambilan asid amino bebas apabila

G. antarctica dikultur dalam medium kompleks dan medium minimum

\section{ANALISIS KUMPULAN BIOSINTESIS ASID} AMINO SECARA DE NOVO

Tapak jalan biosintesis 20 asid amino boleh dibahagikan kepada lima kumpulan mengikut substrat primer metabolisme yang digunakan iaitu tapak jalan keluarga serina, keluarga aromatik, keluarga piruvat, keluarga glutamat dan keluarga aspartat (Payne \& Loomis 2006).. Berdasarkan hasil analisis jujukan homologi protein biosintesis asid amino $S$. cerevisiae, terdapat sebanyak 187 jujukan EST daripada kedua-dua perpustakaan cDNA medium pertumbuhan yang terlibat dalam biosintesis asid amino telah dikenal pasti. Bagi menentukan tahap pengekspresan gen yang terlibat dalam biosintesis asid amino, beberapa gen yang terlibat dalam setiap tapak jalan biosintesis dipilih untuk analisis RT-qPCR.

Tiga gen mengekod enzim yang terlibat dalam tapak jalan biosintesis asid amino keluarga serina dipilih iaitu sistationina $\beta$-sintase ( $C B S 1)$, serina hidrosimetiltransferase $(G S H 1)$ dan D-3-fosfogliserat dehidrogenase (GPDl). Enzim sistationina $\beta$-sintase bertindak sebagai pemangkin tindak balas penghasilan asid amino sistina daripada sebatian sistationina. Manakala enzim serina hidrosimetiltransferase bertindak sebagai pemangkin tindak balas asid amino serina kepada glisina. Seterusnya, enzim D-3-fosfogliserat dehidrogenase merupakan pemangkin kepada tindak balas sebatian 3-fosfogliserat kepada sebatian 3-fosfohidrosipiruvat. Pengekspresan enzim ini dalam kedua-dua medium pertumbuhan ditunjukkan pada Rajah 3(A). Ketiga-tiga gen tersebut menunjukkan profil pengekspresan yang lebih tinggi di dalam medium pertumbuhan minimum berbanding medium pertumbuhan kompleks. Pemerhatian ini mencadangkan dalam keadaan kekurangan asid amino dalam medium pertumbuhan, gengen terlibat dalam biosintesis asid amino bagi keluarga serina akan diekspres dengan tinggi bagi membolehkan sel mensintesis asid amino tersebut secara terus. Selain itu, pengekspresan gen mengekod D-3-fosfogliserat dehidrogenase di dalam medium pertumbuhan minimum adalah lebih tinggi berbanding pengekspresan gen mengekod sistationina $\beta$-sintase dan gen mengekod serina hidrosimetiltransferase. Ini mungkin kerana enzim D-3fosfogliserat dehidrogenase merupakan enzim pertama terbitan tapak jalan biosintesis keluarga serina dan pengekspresannya mempengaruhi sintesis asid aminoasid amino lain yang merupakan produk akhir tapak jalan biosintesis (Okamura \& Hirai 2017).

Tapak jalan biosintesis keluarga aromatik menghasilkan tiga produk akhir iaitu asid amino triptofan, fenilalanina dan tirosina. Sintesis ketiga-tiga asid amino ini merupakan antara yang terendah disebabkan penggunaan tenaga ATP yang banyak (Maeda \& Dudareva 2012). Dalam kajian ini, tiga gen mengekod enzim korismat mutase (GCMl), enzim korismat sintase (GCSI) dan enzim triptofan sintase (GTS1) telah dipilih untuk kajian pengekspresan gen. Didapati tahap pengekspresan GCS I, GCMl dan GTS l adalah tinggi di dalam medium minimum berbanding medium kompleks (Rajah 3(B)). Selain itu, tahap pengekspresan GCS1 adalah lebih rendah berbanding GCM1 dan GTS1 di dalam medium minimum mungkin disebabkan peranan enzim korismat sintase sebagai pemangkin tindak balas akhir laluan penghasilan korismat (Kitzing et al. 2004). Sebatian korismat penting dalam pengawalaturan aliran sebatian karbon di dalam tapak jalan biosintesis famili aromatik.

Produk akhir bagi tapak jalan biosintesis keluarga piruvat adalah asid amino leusina, valina, isoleusina dan alanina. Empat gen mengekod enzim yang terlibat di dalam biosintesis keluarga piruvat dipilih untuk kajian pengekspresan gen iaitu isopropilmalat sintase (GISl), isopropilmalat dehidrogenase (GIDl), dihidrosiasid dehidratase $(G D D l)$ dan asetolaktat sintase (GASl). Didapati pengekspresan GIS1, GIDl dan GASl adalah tinggi di dalam medium minimum berbanding medium kompleks manakala pengekspresan GDDl pula adalah sebaliknya (Rajah 3(C)). Ini mungkin kerana enzim dihidrosiasid dehidratase merupakan pemangkin tindak balas substrat $\alpha$-keto-isovalerat yang berfungsi sebagai pengawal atur untuk mengagihkan struktur $\alpha$-keto kepada asid amino valina dan leusina (Kohlhaw 2003). Selain itu, tapak jalan biosintesis keluarga piruvat melibatkan tiga rantaian bercabang sintesis asid amino yang saling berkait dan enzim di dalam mitokondria dan sitosol yang saling berinteraksi (Kohlhaw 2003). Tapak jalan biosinteis asid amino keluarga piruvat menjadi semakin rumit apabila prekursor ketiga-tiga tapak jalan berkongsi analog yang sama. Justeru, pelbagai interaksi boleh berlaku antara tapak jalan síntesis ketigatiga asid amino tersebut antaranya gangguan terhadap kawalan produk akhir, kawalan penindasan dan mungkin melibatkan gangguan semasa pembentukan protein yang melibatkan salah satu daripada asid amino tersebut.

Tapak jalan biosintesis keluarga glutamat menghasilkan lima produk akhir asid amino iaitu glutamat, glutamina, lisina, arginina dan prolina. Di dalam kajian ini, asid amino lisina telah dikelompokkan bersama famili glutamat kerana asid amino lisina bagi sesetengah organisma seperti yis akan berkongsi laluan utama dan substrat primer ( $\alpha$-ketoglutarat) bersama ahli-ahli famili glutamat yang 
lain (Zabriskie \& Jackson 2000). Gen mengekod enzim NADP-spesifik glutamat dehidrogenase ( $N G D 1)$, ornitin karbamoiltransferase (GOCl), sakarofin dehidrogenase (GSDl) dan argininosuksinat liase (GALl) telah dipilih untuk analisis pengekspresan gen melalui kaedah RTqPCR. Keempat-empat gen yang dikaji mempunyai tahap pengekspresan yang tinggi pada medium minimum berbanding medium kompleks (Rajah 3(D)). Kajian lepas telah membuktikan pada keadaan persekitaran normal (tiada kekurangan asid amino), glutamat boleh didapati dengan mudah melalui penukaran glutamina kepada glutamat oleh enzim glutamina sintetase (Coutts et al. 2002) yang secara langsung menyokong keputusan yang diperoleh dalam kajian ini. Enzim ornitin karbamoiltransferase dan enzim argininosuksinat liase pula merupakan pemangkin tindak balas pada laluan akhir (ornitin kepada arginina) dalam sintesis asid amino arginina. Oleh yang demikian, pengekspresan kedua-dua gen tersebut yang tinggi dalam medium minimum adalah selari dengan kekurangan asid amino arginina dalam sel.

A)

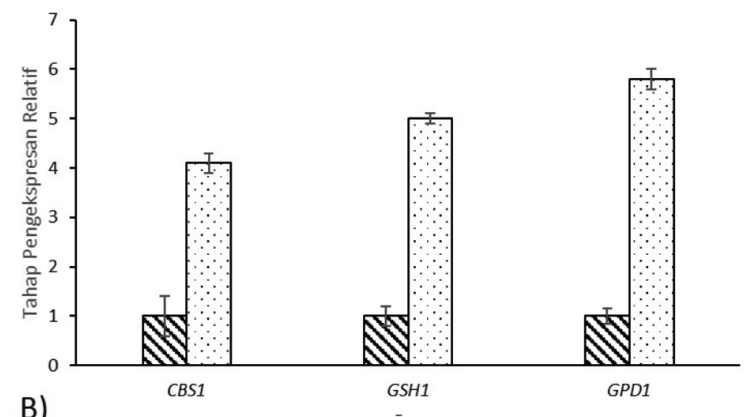

B)

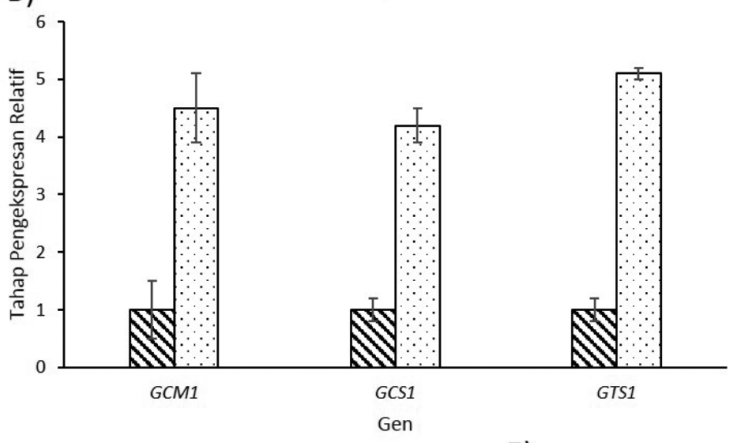

E)
Tapak jalan biosintesis keluarga aspartat pula menghasilkan asid amino seperti aspartat, asparagina, treonina, metionina dan isoleusina. Empat enzim yang terlibat dalam tapak jalan ini telah dipilih untuk kajian pengekspresan gen iaitu enzim aspartat aminotransferase (GAAl), aspartat kinase (GAKl), asparagina sintetase (ASTl) dan isoleusina aminotransferase rantai-bercabang (AATl). Keputusan analisis menunjukkan tahap pengekpresan GAAl, GAKl dan AATl adalah tinggi di dalam medium kompleks berbanding medium pertumbuhan minimum manakala tahap pengekspresan ASTl menunjukkan sebaliknya (Rajah 3(E)). Ini berkemungkinan disebabkan kehadiran sebatian ammonia di dalam medium minimum yang menjadi sumber nitrogen dan penderma kumpulan amino yang seterusnya meningkatkan proses sintesis asid amino asparagina di dalam kultur medium tersebut (Yin et al. 2017). Bagi tapak jalan biosintesis asid amino aspartat pula, tindak balas laluan ini menggunakan asid amino glutamat sebagai penderma kumpulan amino dan nitrogen. Faktor ini mungkin menyebabkan hasil pengekspresan

C)
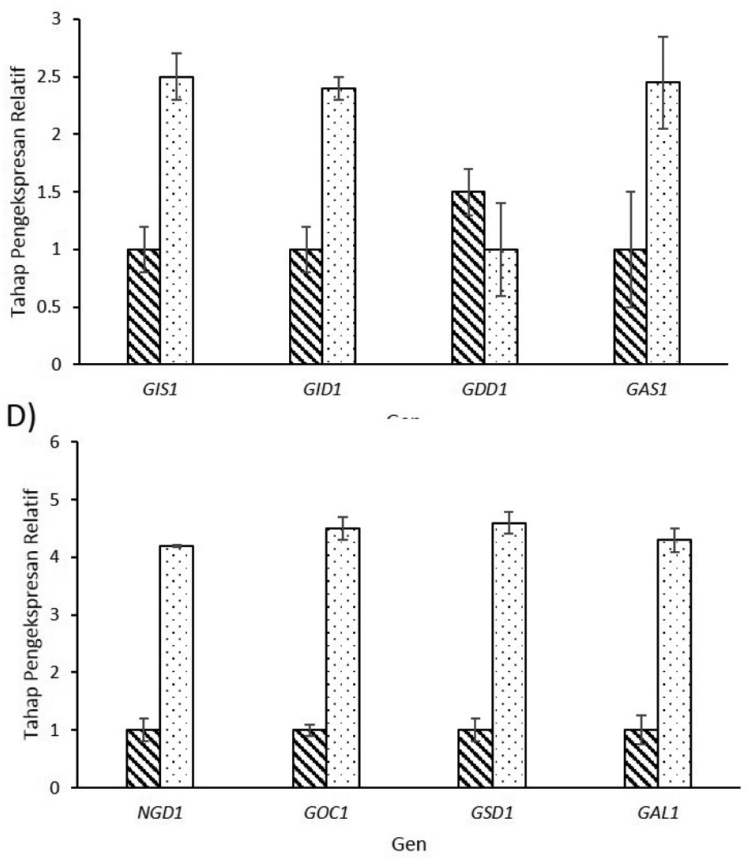

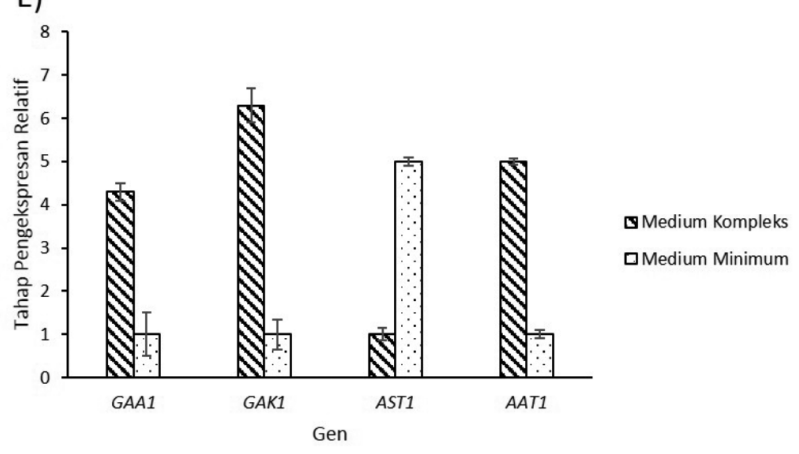

RAJAH 3. Analisis tahap pengekspresan relatif bagi gen-gen yang terlibat di dalam biosintesis asid amino de novo pada beberapa tapak jalan biosintesis yang berbeza: (A) famili serina, (B) famili aromatic, (C) famili piruvat, (D) famili glutamat dan (E) famili aspartate, apabila G. antarctica dikultur dalam medium kompleks dan medium minimum 
GAAl yang diperoleh di dalam medium minimum adalah lebih rendah berbanding medium kompleks. Di samping itu, pengekspresan GAAl juga mempengaruhi tahap pengekspresan GAKl dan AATl kerana aktiviti enzim aspartat kinase dan isoleusina aminotransferase rantaibercabang berada pada tapak jalan yang sama dengan enzim aspartat aminotransferase.

Secara umumnya, kadar pengekspresan enzim pada tapak jalan biosintesis asid amino pada $G$. antarctica tersebut adalah bergantung kepada komposisi asid amino pada sesuatu keadaan bagi mengelakkan sebarang penindasan aktiviti enzim atau kehilangan produk akhir bagi salah satu tapak jalan biosintesis asid amino. Keadaan ini secara tidak langsung akan dapat mengekalkan kuantiti asid amino pada keadaan minimum apabila keadaan persekitaran berkapasiti asid amino rendah dan memerlukan kepada sintesis asid amino untuk menampung keperluan sel.

\section{ANALISIS KUMPULAN PENGAWALATURAN KITAR SEMULA ASID AMINO}

Kekurangan asid amino adalah rangsangan fisiologi yang membawa banyak perubahan di dalam sel. Dua kesan utama kekurangan asid amino adalah penurunan sintesis protein dan pengaktifan tapak jalan proteolitik (Gretzmeier et al. 2017). Pilihan utama mekanisme proteolitik di dalam organisma eukariot adalah melalui sistem ubikuitin-proteosom yang merupakan gabungan mekanisme konjugasi ubikuitin dan protein proteosom $26 \mathrm{~S}$ (Tu et al. 2012). Sistem ini berperanan untuk mengawal kualiti protein melalui pemusnahan protein rosak selain bertindak sebagai suis biokimia untuk mengawal kepekatan dan paras komponen pembinaan protein di dalam sel (Good et al. 2011). Kajian juga mendapati sistem ubikuitinproteosom merupakan tapak jalan utama bagi degradasi protein di dalam model organisma yis S. cerevisiae (Finley et al. 2012).

Degradasi protein melalui tapak jalan ubikuitinproteosom melibatkan tiga enzim iaitu enzim pengaktif ubikuitin, enzim konjugasi ubikuitin dan enzim ubikuitin ligase (Lecker et al. 2006). Terdapat satu jujukan EST $G$. antarctica daripada perpustakaan cDNA medium minimum berhomologi dengan jujukan enzim pengaktif ubikuitin $S$. cerevisiae. Bagi enzim konjugasi ubikuitin pula, sebanyak tujuh jujukan EST yang berhomologi telah dikenal pasti di dalam setiap perpustakaan cDNA medium kompleks dan medium minimum manakala bagi enzim ubikuitin ligase pula, terdapat satu jujukan EST yang homolog di dalam perpustakaan cDNA medium kompleks. Tiga jujukan EST $G$. antarctica yang mengekod enzim pengaktif ubikuitin (GUAl), enzim konjugasi ubikuitin (GUCl) dan enzim ubikuitin ligase (GUL1) telah dipilih untuk dianalisis kadar pengekspresan gen masing-masing di dalam kedua-dua medium tersebut. Berdasarkan Rajah 4, pengekspresan gen bagi ketiga-tiga enzim tersebut adalah lebih tinggi di dalam medium pertumbuhan minimum berbanding medium pertumbuhan kompleks. Pemerhatian ini mungkin disebabkan oleh peranan ketiga-tiga enzim ini dalam mengenal pasti dan menandakan protein berjangka hayat pendek yang menjadi pilihan utama untuk didegradasi dalam keadaan persekitaran nutrien yang terhad bagi menampung kekurangan bekalan asid amino (Lecker et al. 2006). Oleh yang demikian, regulasi protein yang tepat pada masanya adalah penting untuk menjamin kemandirian dan perkembangan sel tersebut (Wittenberg \& Reed 2005).

\section{KESIMPULAN}

Kajian ini telah berjaya mengenal pasti dan menciri beberapa gen $G$. antarctica yang terlibat dalam metabolisme asid amino. Kehadiran gen yang mengekod protein terlibat dalam pengambilan asid amino, sintesis asid amino serta kitar semula asid amino membuktikan bahawa mekanisme penjanaan asid amino bagi mikroorganisma psikrofil adalah terpulihara seperti mikroorganisma mesofil. Kajian ini juga mencadangkan apabila yis psikrofil hidup di dalam medium yang kaya dengan nutrien, ia akan mengambil asid amino daripada persekitaran dengan meningkatkan penghasilan permease yang terlibat dalam pengambilan asid amino bebas. Namun apabila ia hidup dalam persekitaran kurang nutrien, yis ini akan mensintesis asid amino yang diperlukan ataupun akan mengitar semula protein yang telah rosak bagi memperoleh asid amino

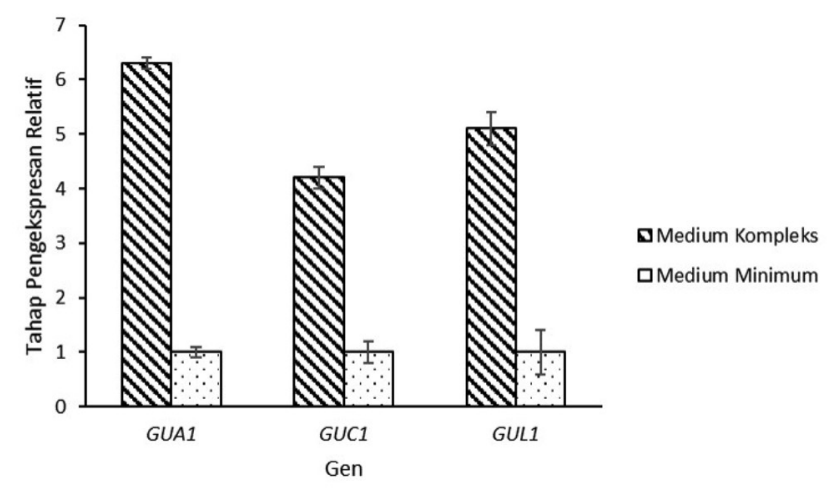

RAJAH 4. Analisis tahap pengekspresan relatif bagi gen mengekod enzim pengaktif ubikuitin (GUAl), enzim konjugasi ubikuitin (GUCl) dan enzim ubikuitin ligase (GUL1) daripada kumpulan pengawalaturan kitar semula asid amino apabila $G$. antarctica dikultur dalam medium kompleks dan medium minimum 
untuk menyokong pertumbuhannya. Maklumat yang diperoleh mencadangkan mekanisme pengambilan dan penghasilan asid amino bagi yis psikrofil ini adalah sama seperti mikroorganisma mesofil yang lain.

\section{PENGHARGAAN}

Penyelidikan ini telah dibiayai oleh geran penyelidikan 07-05-MGI-GMB014 dan 08-05-MGI-GMB001 daripada Kementerian Sains, Teknologi dan Inovasi, Malaysia.

\section{RUJUKAN}

Andréasson, C., Neve, E.P.A. \& Ljungdah, P.O. 2004. Four permeases import proline and the toxic proline analogue azetidine-2-carboxylate into yeast. Yeast 21: 193-199.

Bharudin, I.,Zaki, N.Z., Bakar, F.D.A., Mahadi, N.M., Najimudin, N., Illias, R.M. \& Murad, A.M.A. 2014. Comparison of RNA extraction methods for transcript analysis from the psychrophilic yeast, Glaciozyma antarctica. Malaysian Applied Biology 43: 71-79.

Boer, V.M., Amini, S. \& Botstein, D. 2008. Influence of genotype and nutrition on survival and metabolism of starving yeast. Proceedings of the National Academy of Sciences of the United States of America 105: 6930-6935.

Conesa, A., Götz, S., García-Gómez, J.M., Terol, J., Talón, M. \& Robles, M. 2005. Blast2GO: A universal tool for annotation, visualization and analysis in functional genomics research. Bioinformatics 21: 3674-3676.

Coutts, G., Thomas, G., Blakey, D. \& Merrick, M. 2002. Membrane sequestration of the signal transduction protein GlnK by the ammonium transporter AmtB. The EMBO Journal 21: 536-545.

D’Amico, S., Collins, T., Marx, J.C., Feller, G., Gerday, C. \& Gerday, C. 2006. Psychrophilic microorganisms: Challenges for life. EMBO Reports 7: 385-389.

Ewing, B. \& Green, P. 1998. Base-calling of automated sequencer traces using phred. II. Error probabilities. Genome Research 8(3): 186-194.

Finley, D., Ulrich, H.D., Sommer, T. \& Kaiser, P. 2012. The ubiquitin-proteasome system of Saccharomyces cerevisiae. Genetics 192: 319-360.

Firdaus-Raih, M., Hashim, N.H.F., Bharudin,I.,Abu Bakar, M.F., Huang, K.K., Alias, H., Lee, B.K.B., Mat Isa, M.N., MatSharani, S., Sulaiman, S., Tay, L.J., Zolkefli, R., Muhammad Noor, Y., Law, D.S.N., Abdul Rahman, S.H., Md-Illias, R., Abu Bakar, F.D., Najimudin, N., Abdul Murad, A.M. \& Mahadi, N.M. 2018. The Glaciozyma antarctica genome reveals an array of systems that provide sustained responses towards temperature variations in a persistently cold habitat. PLoS One 13: e0189947.

George, R.A. 2001. StackPACK clustering system. Briefings in Bioinformatics 2: 394-397.

Good, M.C., Zalatan, J.G. \& Lim, W.A. 2011 . Scaffold proteins: Hubs for controlling the flow of cellular information. Science 332: 680-686.

Gretzmeier, C., Eiselein, S., Johnson, G.R., Engelke, R., Nowag, H., Zarei, M., Küttner, V., Becker, A.C., Rigbolt, K.T.G., Høyer-Hansen, M., Andersen, J.S., Münz, C., Murphy, R.F. \& Dengjel, J. 2017. Degradation of protein translation machinery by amino acid starvation-induced macroautophagy. Autophagy 13: 1064-1075.
Hashim, N.H.F., Bharudin, I., Nguong, D.L.S., Higa, S., Bakar, F.D.A., Nathan, S., Rabu, A., Kawahara, H., Illias, R.M., Najimudin, N., Mahadi, N.M. \& Murad, A.M.A. 2013. Characterization of Afp1, an antifreeze protein from the psychrophilic yeast Glaciozyma antarctica PI12. Extremophiles 17: 63-73.

Iraqui, I., Vissers, S., Bernard, F., de Craene, J.O., Boles, E., Urrestarazu, A. \& André, B. 1999. Amino acid signaling in Saccharomyces cerevisiae: A permease-like sensor of external amino acids and F-box protein Grrlp are required for transcriptional induction of the $A G P 1$ gene, which encodes a broad-specificity amino acid permease. Molecular and Cellular Biology 19: 989-1001.

Jørgensen, M.U., Bruun, M.B., Didion, T. \& Kielland-Brandt, M.C. 1998. Mutations in five loci affecting GAP1independent uptake of neutral amino acids in yeast. Yeast 14: 103-114.

Kitzing, K., Auweter, S., Amrhein, N. \& Macheroux, P. 2004. Mechanism of chorismate synthase. Role of the two invariant histidine residues in the active site. Journal of Biological Chemistry 279(10): 9451-9461.

Klasson, H., Fink, G.R. \& Ljungdahl, P.O. 1999. Ssy1p and Ptr3p are plasma membrane components of a yeast system that senses extracellular amino acids. Molecular and Cellular Biology 19: 5405-5416.

Kohlhaw, G.B. 2003. Leucine biosynthesis in fungi: Entering metabolism through the back door. Microbiology and Molecular Biology Reviews 67: 1-15.

Lecker, S.H., Goldberg, A.L. \& Mitch, W.E. 2006. Protein degradation by the ubiquitin-proteasome pathway in normal and disease states. Journal of the American Society of Nephrology 17: 1807-1819.

Maeda, H. \& Dudareva, N. 2012. The shikimate pathway and aromatic amino acid biosynthesis in plants. Annual Review of Plant Biology 63: 73-105.

Moyer, C.L. \& Morita, R.Y. 2007. Psychrophiles and Psychrotrophs. Encyclopedia of Life Science. New Jersey: John Wiley \& Sons, Ltd. pp. 1-6.

Murad, A.M.A., Badrun, R., Shahabudin, S., Kamaruddin, S., Zairun, M.A., Khairuddin, F., Mahadi, N.M., Illias, R.M., Zainal, Z. \& Bakar, F.D.A. 2013. Pengenalpastian dan pencirian gen Trichoderma virens UKM1 mengekod enzim terlibat dalam pencuraian kitin krustasea. Sains Malaysiana 42(6): 715-724.

Okamura, E. \& Hirai, M.Y. 2017. Novel regulatory mechanism of serine biosynthesis associated with 3-phosphoglycerate dehydrogenase in Arabidopsis thaliana. Scientific Reports 7 : 3533.

Payne, S.H. \& Loomis, W.F. 2006. Retention and loss of amino acid biosynthetic pathways based on analysis of wholegenome sequences. Eukaryotic Cell 5: 272-276.

Petti, A.A., Crutchfield, C.A., Rabinowitz, J.D. \& Botstein, D 2011. Survival of starving yeast is correlated with oxidative stress response and nonrespiratory mitochondrial function. Proceedings of the National Academy of Sciences of the United States of America 108: E1089-E1098.

Schmidt, M.C., McCartney, R.R., Zhang, X., Tillman, T.S., Solimeo, H., Wölfl, S., Almonte, C. \& Watkins, S.C. 1999. Std1 and Mth1 Proteins interact with the glucose sensors to control glucose-regulated gene expression in Saccharomyces cerevisiae. Molecular and Cellular Biology 19: 4561-4571.

Spellman, P.T., Sherlock, G., Zhang, M.Q., Iyer, V.R., Anders, K., Eisen, M.B., Brown, P.O., Botstein, D. \& Futcher, B. 
1998. Comprehensive identification of cell cycle-regulated genes of the yeast Saccharomyces cerevisiae by microarray hybridization. Molecular Biology of the Cell 9: 3273-3297.

Springael, J.Y. \& André, B. 1998. Nitrogen-regulated ubiquitination of the Gap1 permease of Saccharomyces cerevisiae. Molecular Biology of the Cell 9: 1253-1263.

Stekel, D.J., Git, Y. \& Falciani, F. 2000. The comparison of gene expression from multiple cDNA libraries. Genome Research 10: 2055-2061.

Sterky, F. \& Lundeberg, J. 2000. Sequence analysis of genes and genomes. Journal of Biotechnology 76: 1-31.

Susko, E. \& Roger, A.J. 2004. Estimating and comparing the rates of gene discovery and expressed sequence tag (EST) frequencies in EST surveys. Bioinformatics 20: 2279-2287.

Thevelein, J.M., Geladé, R., Holsbeeks, I., Lagatie, O., Popova, Y., Rolland, F., Stolz, F., Van de Velde, S., Van Dijck, P., Vandormael, P., Van Nuland, A., Van Roey, K., Van Zeebroeck, G. \& Yan, B. 2005. Nutrient sensing systems for rapid activation of the protein kinase A pathway in yeast. Biochemical Society Transactions 33(1): 253-256.

Tang, C., Gong, M., Li, S. \& Zhu, C. 2012. Construction of cDNA library of Aspergillus niger $\mathrm{H} 1$ and screening of phosphate-dissolving related gene. Wei Sheng Wu Xue Bao 52(3): 311-317.

Tu, Y., Chen, C., Pan, J., Xu, J., Zhou, Z.G. \& Wang, C.Y. 2012. The ubiquitin proteasome pathway (UPP) in the regulation of cell cycle control and DNA damage repair and its implication in tumorigenesis. International Journal of Clinical and Experimental Pathology 5: 726-738.

Wittenberg, C. \& Reed, S.I. 2005. Cell cycle-dependent transcription in yeast: Promoters, transcription factors, and transcriptomes. Oncogene 24(17): 2746-2755.

Yin, H., Zhang, R., Xia, M., Bai, X., Mou, J., Zheng, Y. \& Wang, M. 2017. Effect of aspartic acid and glutamate on metabolism and acid stress resistance of Acetobacter pasteurianus. Microbial Cell Factories 16(1): 109.

Zabriskie, T.M. \& Jackson, M.D. 2000. Lysine biosynthesis and metabolism in fungi. Natural Product Reports 17(1): 85-97.

Zhang, P., Du, G., Zou, H., Chen, J., Xie, G., Shi, Z. \& Zhou, J. 2016. Effects of three permeases on arginine utilization in Saccharomyces cerevisiae. Scientific Reports 6: 20910.
Izwan Bharudin, Radziah Zolkefli, Shazilah Kamaruddin, Farah Diba Abu Bakar \& Abdul Munir Abdul Murad* Pusat Pengajian Biosains dan Bioteknologi

Fakulti Sains dan Teknologi

Universiti Kebangsaan Malaysia

43600 UKM Bangi, Selangor Darul Ehsan

Malaysia

Mohd Faizal Abu Bakar \& Nor Muhammad Mahadi

Malaysia Genome Institute

Jalan Bangi Lama

43000 Kajang, Selangor Darul Ehsan

Malaysia

Rosli Md. Illias

Department of Bioprocess Engineering

Faculty of Chemical Engineering

Universiti Teknologi Malaysia

81310 Skudai, Johor Darul Takzim

Malaysia

Nazalan Najimudin

School of Biological Sciences

Universiti Sains Malaysia

11800 Pulau Pinang

Malaysia

*Pengarang untuk surat-menyurat; email: munir@ukm.edu.my

Diserahkan: 15 September 2017

Diterima: 12 April 2018 